\title{
Frequency of thiopurine S-methyltransferase gene variations in Turkish children with acute leukemia
}

\author{
Dilara Fatma Akın¹, Deniz Aşlar-Öner², Emin Kürekçi², Nejat Akar ${ }^{3}$ \\ ${ }^{1}$ Department of Medical Biology, Niğde Ömer Halisdemir University, Faculty of Medicine, Nigde, ${ }^{2}$ Department of Pediatric \\ Hematology, Losante Children's and Adult Hospital Ankara, ${ }^{3}$ Department of Pediatric Diseases, TOBB-ETU Hospital, \\ Ankara, Turkey.E-mail: dilarafatmaakin@gmail.com \\ Received: 15th May 2017, Revised: 31st July 2017, Accepted: 17th September 2017
}

SUMMARY: Akın DF, Aşlar-Öner D, Kürekçi E, Akar N. Frequency of thiopurine S-methyltransferase gene variations in Turkish children with acute leukemia. Turk J Pediatr 2018; 60: 147-152.

In this study we aim to determine the genotype distribution and allele frequencies of common TPMT $\left({ }^{*} 2,{ }^{*} 3 \mathrm{~A},{ }^{*} 3 \mathrm{~B}\right.$ and $\left.{ }^{*} 3 \mathrm{C}\right)$ polymorphisms in Turkish children with acute leukemia. The study population consisted of 169 patients aged between 1 and 15 years who were admitted to Losante Pediatric Hematology and Children's Hospital with the diagnosis of acute leukemia. Genotyping of TPMT polymorphisms was screened with real-time PCR using fluorescence melting curve detection analysis. We found that the frequencies of four allelic variants of TPMT are $* 2(238 \mathrm{G}>\mathrm{C})(0,0 \%),{ }^{*} 3 \mathrm{~A}(460 \mathrm{G}>\mathrm{A}$ and $719 \mathrm{~A}>\mathrm{G})(1.7 \%),{ }^{*} 3 \mathrm{~B}(460 \mathrm{G}>\mathrm{A})(1,7 \%)$ and $* 3 \mathrm{C}(719 \mathrm{~A}>\mathrm{G})(2.4 \%)$. Frequency of TPMT alleles increases the efficacy of leukemia treatment. Thus, TPMT genotyping can be useful for optimizing 6-MP therapy.

Key words: TPMT, leukemia, childhood, polymorphism.

Drug metabolizing enzymes play a role in the neutralizing of xenobiotics and biotransformation of drugs. ${ }^{1}$ Polymorphisms in the drug-metabolizing enzyme coding genes change the activity of these enzymes for their substrates. Thiopurine S-methyltransferase (TPMT) is a cytosolic methylating enzyme that preferentially catalyzes the S-methylation (inactivation) of aromatic and heterocyclic sulfhydryl compounds, which include anticancer thiopurine groups such as mercaptopurine, thioguanine, and azathioprine. 2,3 These medications are currently used to treat many diseases, such as cancers, autoimmune diseases and inflammatory diseases. ${ }^{4,5}$

6-Mercaptopurine (6-MP) and 6-thioguanine (6-TG) have been important components of curative therapy for childhood acute lymphoblastic leukemia (ALL) and acute myeloblastic leukemia (AML), respectively. ${ }^{6,7}$ 6-MP is a prodrug which is activated by intracellular multistep pathway to cytotoxic thioguanine nucleotides (TGNs) that are incorporated into DNA repair pathway and trigger cell death. ${ }^{8}$
TPMT displays genetic polymorphisms in different ethnic groups, including Caucasians, Africans, African-Americans, and Asians. Additionally TPMT has been associated with high levels of 6-MP metabolite levels and toxicity. ${ }^{9}$ The TPMT is localized on chromosome 6 p22.3 and consists of 10 exons. ${ }^{10}$ To date more than 20 SNPs for TPMT have been reported. ${ }^{11-13}$ Four alleles $(T P M T * 2, * 3 A, * 3 B$, and $* 3 C$ ) describe for $\sim 95 \%$ of inherited TPMT deficiency and have been biochemically characterized. ${ }^{14-16}$ TPMT ${ }^{*} 3 A$ allele results in an about 400 - fold decrease; TPMT* $3 B$ allele results in a fourfold decrease; $\mathrm{TPMT}^{*} 2$ allele results 100 -fold decrease; TPMT*3C allele results in a 1.4-fold in protein levels. ${ }^{17,18}$ The wild-type allele, TPMT $^{*} 1$, encodes the fully active enzyme. ${ }^{19}$ The frequencies of $T P M T^{*} 2(238 \mathrm{G}>\mathrm{C}), \mathrm{TPMT}^{*} 3 \mathrm{~A}$ $(719 \mathrm{~A}>\mathrm{G}-460 \mathrm{G}>\mathrm{A}) \quad$ TPMT $* 3 B(460 \mathrm{G}>\mathrm{A})$ and TPMT *3C $(719 \mathrm{~A}>\mathrm{G})$ alleles have been reported in different populations as shown in Table I. The molecular defect in TPMT*2 contains $\mathrm{G}>\mathrm{C}$ transversion at position 238 that leads to an amino acid substitution at codon 80 Ala $>$ Pro. ${ }^{20}$ The TPMT*3A contains 

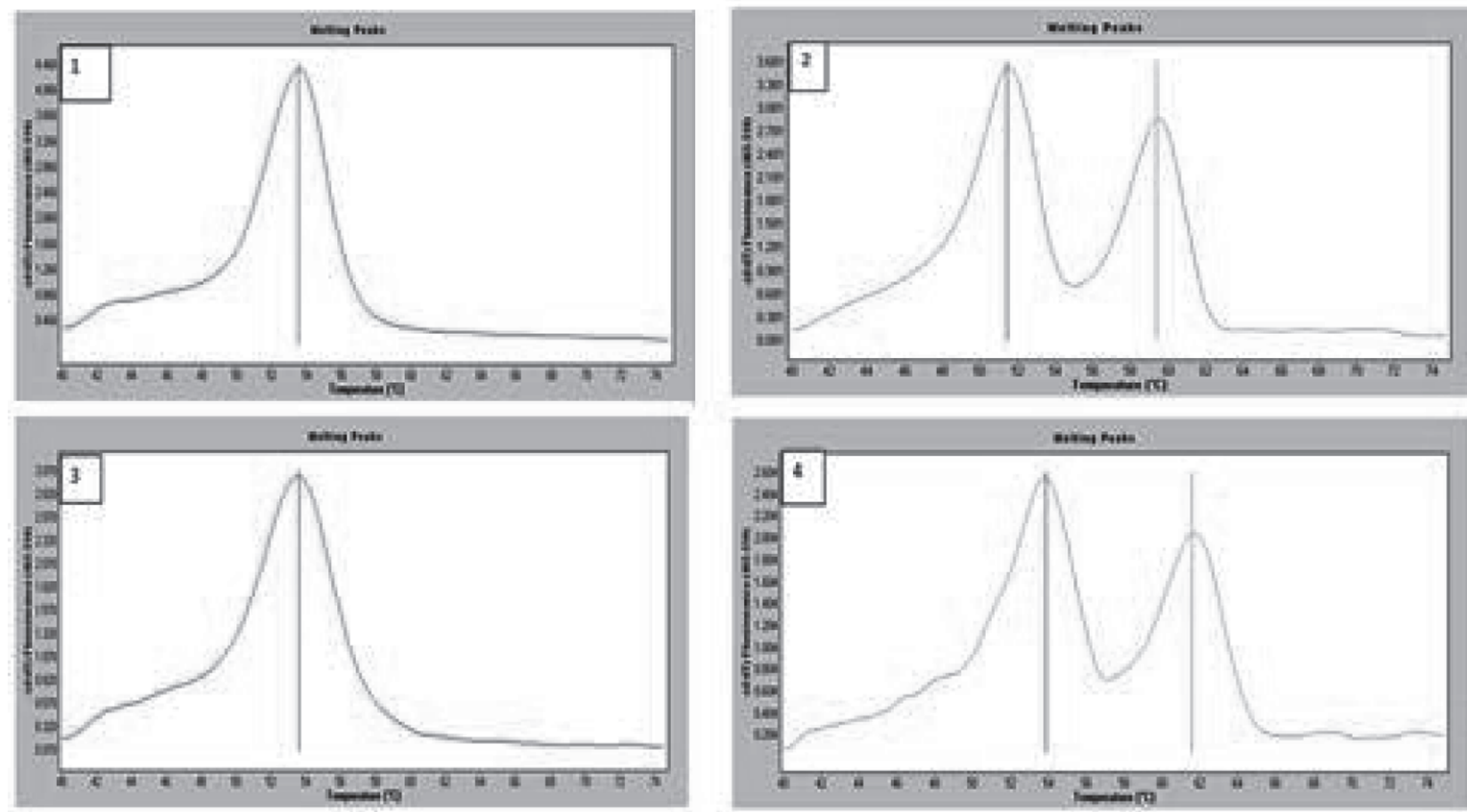

Fig. 1. Melting Curve analysis with the Light Cycler 480 II. These dual peaks show heterozygous samples. (1) TPMT *3C wildtype, (2) TPMT *3C heterozygote (rs1142345), (3) TPMT *3B wildtype, (4) TPMT *3B heterozygote (rs1800460).

two nucleotide transitions $\mathrm{G}>\mathrm{A}$ and $\mathrm{A}>\mathrm{G}$ at positions 460 and 719 that lead to the amino acid substitution at codon $154 \mathrm{Ala}>\mathrm{Thr}$ and at codon $240 \mathrm{Tyr}>$ Cys. $^{21}$ The TPMT*3B contains single nucleotide transition $\mathrm{G}>\mathrm{A}$ at position 460 that lead to the amino acid substitution at codon 154 Ala $>$ Thr. $^{22}$ The TPMT*3C contains $A>G$ transversion at position 719 that leads to the amino acid substitution at codon 240 Tyr $>$ Cys. ${ }^{23}$

These alleles are accounted for more than $80 \%$ of TPMT in Caucasians [24]. The frequencies of four variant TPMT alleles (TPMT *2, TPMT *3B, TPMT *3C, TPMT *3A) accounting for more than $80 \%$ of all low activity cases were determined in children with ALL in Turkish population. ${ }^{25}$

The aim of this study is to determine the genotype distribution and allele frequencies of common TPMT*2, ${ }^{*} 3 A, 3 B$, and $* 3 C$ polymorphisms by melting curve detection analysis with Light Cycler 480 II System in Turkish children with acute leukemia.

\section{Material and Methods}

\section{Patients and sample collections}

Study population consisted of 169 patients (99 males and 70 females) aged between 1 and 15 years who were admitted to Lösante Pediatric Hematology and Children's Hospital and diagnosed with childhood acute leukemia. Patient characteristics were shown in Table I.

An informed written consent was obtained from all the patients' parents. The study was carried out in accordance with the code of Ethics of

Table I. Demographic Features of the Patients.

\begin{tabular}{lll}
\hline & Range-Mean & Age \pm SD \\
\hline Age, years & $1-15$ & $7.8 \pm 3.76$ \\
Gender & & \\
Male & 97 & \\
Female & 72 & \\
Type of disease & & \\
ALL & 151 & \\
AML & 14 & \\
BAL & 4 & \\
\hline
\end{tabular}

ALL: Acute lymphoblastic leukemia; AML: Acute myeloid leukemia; BAL: Biphenotype acute leukemia 
Table II. Genotype Distributions and Frequencies of $\operatorname{TPMT}^{*}(1,2,3 A, 3 B, 3 C)$ Gene Polymorphisms in Turkish Children with Acute Leukemia.

\begin{tabular}{|c|c|c|c|c|c|}
\hline TPMT Allele & SNP Position & $\begin{array}{l}\text { Ref SNP } \\
\text { number }\end{array}$ & $\begin{array}{l}\text { Amino acid } \\
\text { change }\end{array}$ & $\begin{array}{l}\text { Genotype } \\
\text { distributions } \\
\text { (\%) n:169 }\end{array}$ & $\begin{array}{l}\text { Allele } \\
\text { frequencies } \\
(\%) \text { n:169 }\end{array}$ \\
\hline TPMT $* 1$ & Wild Type & & & $165(97.6)$ & 1 \\
\hline TPMT*2 & $238 \mathrm{G}>\mathrm{C}$ & rs1800462 & Ala80Pro & 0.0 & 0.0 \\
\hline TPMT*3A & $\begin{array}{l}460 \mathrm{G}>\mathrm{A}- \\
719 \mathrm{~A}>\mathrm{G}\end{array}$ & $\begin{array}{l}\text { rs1800460- } \\
\text { rs1142345 }\end{array}$ & $\begin{array}{l}\text { Ala154Thr- } \\
\text { Tyr240Cys }\end{array}$ & $3(1.7)$ & $\begin{array}{l}\text { G/0.99-A/0.01 } \\
\text { A/0.98-G/0.02 }\end{array}$ \\
\hline TPMT*3B & $460 \mathrm{G}>\mathrm{A}$ & rs1800460 & Ala154Thr & $3(1.7)$ & G/0.99-A/0.01 \\
\hline TPMT*3C & $719 A>G$ & rs1142345 & Tyr240Cys & $4(2.4)$ & A/0.98-G/0.02 \\
\hline
\end{tabular}

SNP: single nucleotide polymorphism

the World Medical Association (Declaration of Helsinki) for experiments involving humans. The Ankara University, School of Medicine Ethics Committee approved the study protocol (Project No.14-646-14/2014) and informed consent was provided by the patients' parents. Blood samples were collected with EDTAcontaining tubes and DNA was extracted from peripheral blood and bone marrow leukocytes with MagNA Pure automatic DNA isolation instrument (Roche Diagnostics, Manheim, Germany).

\section{TPMT genotyping}

TPMT polymorphisms analyses were performed by real-time PCR (RT-PCR). Genotyping of TPMT mutations were screened with real time PCR using fluorescence melting curve detection analysis by means of the Light Cycler 480 II System (Roche Diagnostics, Manheim, Germany). For G238C (*2), primers are used which flank the region around the potential mutation place and produce an amplicon of 197 bp. For G460A (*3A, *3B) and A719G (*3A, $* 3 \mathrm{C})$, two primer pairs are used generating amplicons of $159 \mathrm{bp}$ and respectively 177 bp. The melting-point curve analysis allows a clear identification of wildtype, heterozygous or homozygous genotypes.

\section{Statistical analysis}

The chi-square test was used to compare categorical variables. $\mathrm{P}$ value of $<0.05$ was considered statistically significant. Allelic frequencies were calculated by gene-counting method and the genotype distribution with Hardy- Weinberg expectations were determined by $\chi^{2}$ and Fisher's exact tests.

\section{Results}

In this study, we performed Real Time PCR method to detect three types of polymorphisms of the human TPMT. Three TPMT polymorphisms; G238C substitution located in exon 5 region, G460A substitution located in exon 7 region, and A719G substitution located in exon 10 region. TPMT genotypes of the most prevalent mutant allele's (TPMT ${ }^{*} 2,{ }^{*} 3 A,{ }^{*} 3 B$ and ${ }^{*} 3 C$ ) variant genotypes were determined in 169 Turkish children with leukemia who were diagnosed with ALL and AML.

As presented in Table II, three $(1.7 \%)$ patients carried G460A polymorphism in heterozygote state, thus named as carriers of TPMT*3B. Three (1.7\%) patients carried both G460A and A719G polymorphisms and were named TPMT*3A. Four $(2.4 \%)$ patients carried polymorphism A719G indicating to have heterozygote state TPMT*3C. TPMT*2 polymorphism was not detected in 169 patients. The patients that carried none of these variants were named as $T P M T^{*} 1$ and one hundred sixty-five samples (165 of 169 subjects) carried the TPMT

The genotype frequencies of TPMT polymorphisms in healthy individuals from different countries were given in Table III.

\section{Discussion}

TPMT catalyzes the methylation of thiopurine drugs such as azathioprine and 6-mercaptopurine. ${ }^{26}$ TPMT enzyme activity is influenced by polymorphisms in the TPMT gene. ${ }^{27-29}$ Thus, heterozygous alleles have intermediate TPMT activity, homozygous alleles have low TPMT activity and both of them have greater risk of developing thiopurine-induced 
Table III. The Genotype Distribution (\%) of TPMT Polymorphism in Healthy Individuals From Different Country.

\begin{tabular}{|c|c|c|c|c|c|}
\hline \multirow{2}{*}{$\begin{array}{l}\text { Study } \\
\text { Group(n) }\end{array}$} & \multirow[t]{2}{*}{ Population } & & \multicolumn{2}{|c|}{ Genotype distribution (\%) } & \multirow[t]{2}{*}{ References } \\
\hline & & TPMT $* 2$ & TPMT*3A & TPMT*3C & \\
\hline 382 & France & 0.7 & 3.0 & 0.4 & [9] \\
\hline 296 & Turkey & 2.0 & 1.0 & 1.4 & [30] \\
\hline 398 & England & 0.5 & 4.5 & 0.3 & [37] \\
\hline 564 & America & 0.2 & 3.2 & 0.2 & [38] \\
\hline 2428 & Germany & 0.2 & 4.4 & 0.4 & [39] \\
\hline 206 & Italy & 0.4 & 3.9 & 0.9 & [40] \\
\hline 384 & Japan & 0.0 & 0.0 & 1.6 & [41] \\
\hline 254 & Iran & 3.93 & 0.87 & 1.57 & [42] \\
\hline 400 & Chinese & 0 & 0 & 3 & [43] \\
\hline 654 & Kazakhstan & 0.0 & 0.3 & 0.9 & [43] \\
\hline
\end{tabular}

myelosuppression. Therefore, it is indispensable to have knowledge about TPMT SNP frequencies in a population to evaluate the safety and efficacy of ALL treatment. Accordingly, this study was undertaken to determine the prevalence of the TPMT mutations in Turkish children with acute leukemia. We found that genotype distribution of the most relevant TPMT polymorphisms in Turkish children with acute leukemia were $2.4 \%$.

Differences in TPMT polymorphisms change among ethnic groups, ranging from $2 \%$ to $14 \%$ prevalence. TPMT*2 and $* 3$ alleles are the most common mutant alleles in Caucasians ${ }^{30}$. Sayitoglu et al. ${ }^{31}$ detected a prevalence of the TPMT $^{*} 2$, TPMT $^{*} 3 B$ and ${ }^{*} 3 C$ in Turkish healthy individuals, $2 \%, 0 \%$, and $1.4 \%$, respectively. However, we did not detect TPMT*2 alleles in Turkish children with leukemia. When their data in Turkish healthy individuals compared to ours in present study, $3 \mathrm{~B}$ and $3 \mathrm{C}$ genotype prevalence were found higher in our Turkish children with leukemia. Tumer et al's. ${ }^{25}$ data on the frequency of TPMT variants in the Turkish population on 106 Turkish children with ALL revealed the frequency of the TPMT*2, TPMT*3B and $3 C^{*}$ in their study group, $\% 0,0.9 \%$, and $0.9 \%$, respectively. Their genotype frequencies were found lower than our results.

A study by Hongeng et al..$^{32}$ analyzed TPMT genotype status of 75 Thai children with ALL. They detected only ${ }^{*} 3 \mathrm{C}$ allele $(11 \%)$. They reported that there was no difference in the genetic variation of TPMT between Asian and North American Caucasian populations. Lennard et al. ${ }^{33}$ who studied 1320 children with ALL in England reported that TPMT *3B allele was not detected, $* 3 \mathrm{~A}$ and $* 3 \mathrm{C}$ allele frequencies were $4.5 \% 0.7 \%$ respectively. Ayesh et al. ${ }^{29}$ studied 56 children with ALL in Gaza Strip and TPMT*2, TPMT* $3 B$ and TPMT* $3 C$ were not found. ${ }^{*} 3 \mathrm{~A}$ allele frequency in their study group was found $0.89 \%$. Zgheib et al. ${ }^{34}$ who analyzed 127 children with ALL in Lebanon have reported that none of the patients were homozygous alleles while three patients were heterozygous TPMT* $3 \mathrm{~A}(2.4 \%)$ alleles. Farfan et al. ${ }^{35}$ who studied 103 Chilean children with leukemia have reported that the total frequency of TPMT alleles was $8 \%$. TPMT*2, TPMT* $3 A$ and $T P M T^{*} 3 B$ alleles were found in $0 \%, 7 \%$, and $1 \%$, respectively. In the study performed by Chrzanowska et al. ${ }^{36}$ (included 98 children with ALL) they have shown a frequency of TPMT*1 $94.4 \%$, TPMT$^{*} 3 A \quad 5.1 \%$ and TPMT*2 $0.5 \%$.

Genotype and phenotype determination studies are needed to identify the predictive power of TPMT genotyping. These results can help to coordinate pretreatment strategies in patients with leukemia requiring thiopurine medication in their standard therapy.

We hope that our results show the presence of genetic causes of TPMT hypoactivity in Turkish population and help to provide genetic strategies to analyze these patients prior to anticancer therapy. 


\section{REFERENCES}

1. Evans WE, Johnson JA. Pharmacogenomics: the inherited basis for interindividual differences in drug response. Annu Rev Genomics Hum Genet 2001; 2: 9-39.

2. Azimi F, Jafariyan M, Khatami S, Mortazavi Y, Azad M. Assessment of Thiopurine-based drugs according to Thiopurine S-methyltransferase genotype in patients with Acute Lymphoblastic Leukemia. Iran J Ped Hematol Oncol 2014; 4: 32-38.

3. Buster EH, van Vuuren HJ, Zondervan PE, Metselaar HJ, Tilanus HW, de Man RA. Thiopurine-methyltransferase and inosine triphosphate pyrophosphatase polymorphism in a liver transplant recipient developing nodular regenerative hyperplasia on low-dose azathioprine. Eur J Gastroenterol Hepatol 2008; 20: 68-72.

4. Krynetski E, Evans WE. Drug methylation in cancer therapy: lessons from the TPMT polymorphism. Oncogene 2003; 22: 7403-7413.

5. McLeod HL, Pritchard SC, Githang'a J, et al. Ethnic differences in thiopurine methyltransferase pharmacogenetics: evidence for allele specificity in Caucasian and Kenyan individuals. Pharmacogenetics 1999; 9: 773-776.

6. Cheok MH, Lugthart S, Evans WE. Pharmacogenomics of acute leukemia. Annu Rev Pharmacol Toxicol 2006; 46: 317-353.

7. Wells RJ, Woods WG, Buckley JD, et al. Treatment of newly diagnosed children and adolescents with acute myeloid leukemia: A children cancer group study. J Clin Oncol 1994; 12: 2367-2377.

8. Lennard L, Maddocks J. Assay of 6-thioguanine nucleotide, a major metabolite of azathioprine, 6-mercaptopurine and 6-thioguanine, in human red blood cells. J Pharm Pharmacol 1983; 35: 15-18.

9. Spire-Vayron de la Moureyre C, Debuysere H, Mastain $\mathrm{B}$, et al. Genotypic and phenotypic analysis of the polymorphic thiopurine S-methyltransferase gene (TPMT) in a European population. Br J Pharmacol 1998; 125: 879-887.

10. Szumlanski C, Otterness D, Her C, et al. Thiopurine methyltransferase pharmacogenetics: human gene cloning and characterization of a common polymorphism. DNA Cell Biol 1996; 15: 17-30.

11. Cheok MH, Lugthart S, Evans WE. Pharmacogenomics of acute leukemia. Annu Rev Pharmacol Toxicol 2006; 46: 317-353.

12. Wall AM, Rubnitz JE. Pharmacogenomic effects on therapy for acute lymphoblastic leukemia in children. Pharmacogenomics J 2003; 3: 128-135.

13. Evans WE, Hon YY, Bomgaars L, et al. Preponderance of thiopurine S-methyltransferase deficiency and heterozygosity among patients intolerant to mercaptopurine or azathioprine. J Clin Oncol 2001; 19: 2293-2301.

14. Relling MV, Gardner EE, Sandborn WJ, et al; Clinical Pharmacogenetics Implementation Consortium. Clinical Pharmacogenetics Implementation Consortium guidelines for thiopurine methyltransferase genotype and thiopurine dosing. Clin Pharmacol Ther 2011; 89: 387-391.
15. Alvarez LL, Venegas MS, Larrondo LM, Becerra NB, Castro AL, Quera RP. Thiopurine Smethyltransferase gene polymorphism in Chilean blood donors. Rev Med Chil 2009; 137: 185-192.

16. Salavaggione OE, Wang L, Wiepert M, Yee VC, Weinshilboum RM. Thiopurine $S$ methyltransferase pharmacogenetics: variant allele functional and comparative genomics. Pharmacogenet Genomics 2005; 15: 801-815.

17. Tai HL, Krynetski EY, Schuetz EG, Yanishevski Y, Evans WE. Enhanced proteolysis of thiopurine S-methyltransferase (TPMT) encoded by mutant alleles in humans (TPMT*3A, TPMT*2): mechanisms for the genetic polymorphism of TPMT activity. Proc Natl Acad Sci U S A 1997; 94: 6444-6449.

18. Wang L, Nguyen TV, McLaughlin RW, Sikkink LA, Ramirez-Alvarado M, Weinshilboum RM. Human thiopurine S-methyltransferase Mpharmacogenetics: variant allozyme misfolding and aggresome formation. Proc Natl Acad Sci USA 2005; 102: 9394-9399.

19. Yates CR, Krynetski EY, Loennechen T, et al. Molecular diagnosis of thiopurine S-methyltransferase deficiency: genetic basis for azathioprine and mercaptopurine intolerance. Ann Intern Med 1997; 126: 608-614.

20. Otterness D, Szumlanski C, Lennard L, et al. Human thiopurine methyltransferase pharmacogenetics: gene sequence polymorphisms. Clin Pharmacol Ther 1997; 62: $60-73$.

21. Collie-Duguid ES, Pritchard SC, Powrie RH, et al. The frequency and distribution of thiopurine methyltransferase alleles in Caucasian and Asian populations. Pharmacogenetics 1999; 9: 37-42.

22. McLeod HL, Miller DR, Evans WE. Azathioprine induced myelosuppression in thiopurine methyltransferase deficient heart-transplant recipient. Lancet 1993; 341:1151.

23. Schutz E, Gummert J, Mohr F, Oellerich M. Azathioprine induced myelosuppression in thiopurine methyltransferase deficient heart transplant recipient. Lancet 1993; 341: 436.

24. Kubota T, Chiba K. Frequencies of thiopurine S-methyltransferase mutant alleles (TPMT*2, *3A, *3B and *3C) in 151 healthy Japanese subjects and the inheritance of TPMT*3C in the family of a propositus. Br J Clin Pharmacol 2001; 51: 475-477.

25. Tumer TB, Ulusoy G, Adali O, Sahin G, Gozdasoglu S, Arinç E. The low frequency of defective TPMT alleles in Turkish population: a study on pediatric patients with acute lymphoblastic leukemia. Am J Hematol 2007; 82: 906-910.

26. McLeod HL, Krynetski EY, Relling MV, Evans WE. Genetic polymorphism of thiopurine methyltransferase and its clinical relevance for childhood acute lymphoblastic leukemia. Leukemia 2000; 14: 567-572.

27. Alves S, Amorim A, Ferreira F, Prata MJ. Influence of the variable number of tandem repeats located in the promoter region of the thiopurine methyltransferase gene on enzymatic activity. Clin Pharmacol Ther 2001; 70: $165-174$. 
28. Yan L, Zhang S, Eiff B, et al. Thiopurine methyltransferase polymorphic tandem repeat: genotype-phenotype correlation analysis. Clin Pharmacol Ther 2000; 68: 210-219.

29. Ayesh BM, Harb WM, Abed AA. Thiopurine methyltransferase genotyping in Palestinian childhood acute lymphoblastic leukemia patients. BMC Hematol 2013; 13: 3 .

30. Isaza C, Henao J, Lopez AM, Cacabelos R. Allelic variants of the thiopurine methyltransferase (TPMT) gene in the Colombian population. Methods Find Exp Clin Pharmacol 2003; 25: 423-429.

31. Sayitoglu AM, Yıldız I, Hatırnaz O, Ozbek U. Common cytochrome p4503A (CYP3A4 and CYP3A5) and thiopurine S-methyl transferase (TPMT) polymorphisms in Turkish population. Turk J Med Sci 2006; 36: 11-15.

32. Hongeng S, Sasanakul W, Chuansumrit A, Pakakasama $S$, Chattananon A, Hathirat P. Frequency of thiopurine S-methyltransferase genetic variation in Thai children with acute leukemia. Med Pediatr Oncol 2000; 35: 410-414.

33. Lennard L, Cartwright CS, Wade R, Richards SM, Vora A. Thiopurine methyltransferase genotype-phenotype discordance and thiopurine active metabolite formation in childhood acute lymphoblastic leukaemia. Br J Clin Pharmacol 2013; 76: 125-136.

34. Zgheib NK, Akra-Ismail M, Aridi C, et al. Genetic polymorphisms in candidate genes predict increased toxicity with methotrexate therapy in Lebanese children with acute lymphoblastic leukemia. Pharmacogenet Genomics 2014; 24: 387-396.

35. Farfan MJ, Salas C, Canales C, et al. Prevalence of TPMT and ITPA gene polymorphisms and effect on mercaptopurine dosage in Chilean children with acute lymphoblastic leukemia. BMC Cancer 2014; 14: 299.
36. Chrzanowska M, Kuehn M, JanuszkiewiczLewandowska D, Kurzawski M, Droździk M. Thiopurine S-methyltransferase phenotype-genotype correlation in children with acute lymphoblastic leukemia. Acta Pol Pharm 2012; 69: 405-410.

37. Ameyaw MM, Collie-Duguid ES, Powrie RH, OforiAdjei D, McLeod HL. Thiopurine methyltransferase alleles in British and Ghanaian populations. Hum Mol Genet 1999; 8: 367-370.

38. Hon YY, Fessing MY, Pui CH, Relling MV, Krynetski EY, Evans WE. Polymorphism of the thiopurine S-methyltransferase gene in African-Americans. Hum Mol Genet 1999; 8: 371-376.

39. Schaeffeler E, Eichelbaum M, Reinisch W, Zanger UM, Schwab M. Three novel thiopurine S-methyltransferase allelic variants $\left(\right.$TPMT$^{*} 20, * 21, * 22$ ) - association with decreased enzyme function. Hum Mutat 2006; 27: 976.

40. Rossi AM, Bianchi M, Guarnieri C, Barale R, Pacifici GM. Genotype-phenotype correlation for thiopurine S-methyltransferase in healthy Italian subjects. Eur J Clin Pharmacol 2001; 57: 51-54.

41. Hiratsuka M, Inoue T, Omori F, Agatsuma Y, Mizugaki M. Genetic analysis of thiopurine methyltransferase polymorphism in a Japanese population. Mutat Res 2000; 448: 91-95.

42. Azad M, Kaviani S, Soleimani M, Noruzinia M, Hajfathali A. Common polymorphism's analysis of thiopurine S-methyltransferase (TPMT) in Iranian population. Cell J (Yakhteh) 2009; 11: 311-316.

43. Wei H, Zhou S, Li C, Zhang J, Wu J, Huang M. Phenotyping and genotyping studies of thiopurine S-methyltransferase in Kazaks. Pharm Res 2005; 22: 1762-1766. 